\title{
PUBLIC MANAGEMENT IN A REAL ESTATE AREA - SOME EMPIRICAL EVIDENCE FROM POLISH MUNICIPALITIES
}

\author{
Bartłomiej Marona, PhD \\ Faculty of Economics and International Relations \\ Cracow University of Economics \\ e-mail:maronab@uek.krakow.pl
}

\begin{abstract}
The main goal of this paper is to present the role of individual concepts of public management in the process of real estate management in Polish municipalities. Special attention was given to New Public Management (NPM) as well as Good Governance (GG). The paper, apart from a review of literature and its critique, is based on the results of a survey conducted among municipalities belonging to the Kraków Metropolitan Area. This study demonstrates that both the NPM and the GG concepts do not constitute a benchmark model in the practice of municipal real estate management in Poland. The concepts are treated more as a set of tools from which the majority of municipalities choose only some, selected instruments.
\end{abstract}

Keywords: public management, real estate management, good governance, new public management, municipalities.

JEL Classification: H 79, L 85.

Citation: Marona B., 2016, Public Management in a Real Estate Area - Some Empirical Evidence from Polish Municipalities, Real Estate Management and Valuation, vol. 24, no. 4, pp. 16-22.

DOI: $10.1515 /$ remav-2016-0026.

\section{Introduction}

In the paper, new trends in public management will be critically examined in the context of real estate management in a Polish municipality. Two models will be considered: New Public Management (NPM) and Public Governance (PG). According to the first posed hypothesis, even if the NPM model is a thing of the past, most of the standards are, nonetheless, still with us in the legacy of practical reforms (HAQUE 2007), and are still visible in the practices of Polish local governments, including in the field of municipal real estate management. According to the second hypothesis, PG, as a broader model of NPM, is becoming more and more popular and, nowadays, is the basic model in Polish municipal real estate management.

The research goal was boiled down to the assessment of the role of individual concepts of public management in the process of real estate management in Polish municipalities. The paper, apart from the review of literature and its critique, is based on the results of a survey conducted among municipalities belonging to the Kraków Metropolitan Area.

\section{Public management - two approaches}

The term public management may be defined in different ways, however, two approaches are particularly important as far as scientific examination is concerned.

The first, broader approach treats public management as a scientific subdiscipline within management studies. It is necessary to refer here to the results of works carried out by the research team managed by S. Cyfert on Defining Subdisciplines in Management Studies (see: CYFERT et al. 2014) and the team managed by S. Sudoł (both teams appointed on the initiative of the Committee on 
Organizational and Management Sciences of the Polish Academy of Sciences) which dealt with ordering the basic notions and terms in management studies (see: SUDOŁ 2014). In the proposals of both teams, public management should be treated as a separate subdiscipline of management studies. In this context, public management, as a research speciality, requires constant in-depth scientific research, both theoretical and empirical, with the subjects of the research being the organization and management processes occurring in public organizations. Therefore, according to PERRY and KRAEMER (1983), we can treat public management as a merger of the normative orientation of traditional public administration and the instrumental orientation of general management (POLLITT, BOUCKAERT 2004, p. 8). It is worth emphasizing here that, according to this approach, as SZUMOWSKI writes (2014), the beginnings of public management are related to the beginnings of contemporary management, which appears along with the first management theories in the scientific understanding in the second half of the $19^{\text {th }}$ century.

Secondly, public management can be treated in a more narrow way, namely as a set of concepts referring to the functioning of the public sector, which developed as a result of numerous deficiencies diagnosed in so-called Weber's ideal bureaucracy model and whose bloom fell in the 1980s, primarily in Anglo-Saxon countries, the USA and Great Britain, and in the second place - in Canada, Australia and New Zealand, and then in many countries of the Old Continent (MARONA 2014). At this occasion, we should mention, in particular, New public management and Public governance. These concepts, introducing a managerial approach to public sector management, aim to ensure the efficiency and effectiveness of public organizations and to improve the quality of the services provided by them. It seems that the application of the public management concept in the sphere of municipal real estate in Poland may be a chance to eliminate numerous deficiencies and improve the effectiveness of the real estate management processes.

In this article, the term public management will be apprehended in terms of the later.

\section{The theoretical base for the research}

Surveys (OECD 1990, 1993) of developments in western public administrations show that managerial reforms are a common dominant trend in almost all OECD member countries. The managerial reforms consist of greater cost-consciousness, providing better customer service, performance budgeting, human resource management, information technology, performance control, and evaluation of results. In an analysis of these reforms, OECD (1995) concluded that, notwithstanding differences in the nature, size and approach to reforms, "a new paradigm for public management" has emerged, which is characterized by the following eight trends:

- devolving authority, providing flexibility,

- ensuring performance, control, accountability,

- developing competition and choice,

- providing responsive service,

- improving the management of human resources,

- optimizing information technology,

- improving the quality of regulation,

- strengthening steering functions at the center.

It is worth stressing here that NPM has never become a universal model, a new paradigm of public sector management, but only a set of tools from which the majority of countries choose only some, depending on their needs (ZALEWSKI 2005, p. 39). And although most of the Western World countries have tried, for some time, in accordance with the spirit of NPM, to introduce a more "managerial" and "business-like" approach to public administration, the process looks different everywhere and proceeds at various speeds and on a various scale (KICKER 2002). However, for the needs of empirical research, it is necessary to adopt a certain set of NPM components. For this, famous research by HOOD (1991) was used, which enumerated seven components of the NPM model and defined the essence of the doctrine and a typical justification. The doctrine includes seven standards:

- "hands-on professional management" in the public sector,

- explicit standards and measures of performance,

- greater emphasis on output control,

- shift to disaggregation of units in the public sector,

- shift to greater competition in public sector, 
- stress on greater discipline and parsimony in resource use.

Since the 1980s, many developed countries have adopted the NPM conceptual ideology in their management of public real estate. According to KASK (2014, p. 194), this has brought along some major changes in the ways of thinking within the governmental bodies and in how public sector real estate assets are handled. A major shift in the ways of thinking has come about for several reasons. Mostly, it was derived from the understanding that, by large, real estate assets for the public sector are an essential cost-center to the state budget and something major must to be done in order to reduce the burden on the taxpayers' money. On the other hand, some governmental bodies view the public sector real estate assets as an easy way to alleviate possible budget deficits.

American research also shows that real estate management is greatly affected by NPM and has become a part of the NPM movement (LU 2011); of course, this approach is implemented to manage fixed assets on different scales and produce different effects. Research by LU (2011), who used a mail survey to explore innovative approaches of fixed asset management in state governments of the United States, will also be used in this study.

Compared to the NPM movement (PUBLIC MANAGEMENT AND..., p. 9), PG pays a lot of attention to how different organizations interact in order to achieve a higher level of desired results - outcomes achieved by citizens and stakeholders. Therefore, we can say that (KICKERT 1997) PG is the "management" of complex networks, consisting of many different actors from the national, provincial, and local government, political and societal groups, pressure, action and interest groups, societal institutions, and private as well as business organizations. PG focuses on basic public values, such as integrity, transparency, accountability, equity and participation in the set of tools, similarly to NPM, for improving efficiency and effectiveness (OECD, 2009). For the needs of the conducted research, the output of a more detailed concept as compared to PG was used, namely Good Governance (GG), which, according to the methodology used by the European Commission (COMUNICATION ... 2001), is based on five basic principles (BACHTLER et al. 2002, p. 3):

- openness (transparent operation, active communication, accessible language),

- participation (wide involvement throughout the policy chain, and especially by central governments),

- accountability (making legislative and executive roles clearer and ensuring that institutions take responsibility for what they do),

- effectiveness (ensuring policies are timely, have clear objectives, are appropriately evaluated, proportionate and involve decision-making at the most suitable level),

- coherence (requiring political leadership and institutional responsibility in ensuring consistency in approach).

The use of the GG concept was determined, on the one hand, by the fact that it can be treated as a more practical and more detailed version of PG (SZUMOWSKI 2014), and, on the other hand, by the possibility to directly refer both to the methodology and findings of the research by GROSS and ŹRÓBEK (2015), who analyzed good governance principles in some public real estate management systems, as well as previous research of the Food Agriculture Organization (FAO) for the United Nations concerning the use of the GG concept in land tenure (GOOD GOVERNANCE ..., 2007). According to FAO, the features of good governance in land tenure and administration include:

- the legitimacy of land agencies and land administrators is widely recognized by citizens,

- land agencies serve all citizens, including the weak as well as the strong,

- land agencies provide services that respond to the needs of their customers, e.g. in the nature of the services and their accessibility,

- the results of the services are consistent, predictable and impartial,

- the services are provided efficiently, effectively and competently,

- the services are provided with integrity, transparency and accountability.

SZUMOWSKI (2012) made an interesting proposal for the operationalization of the GG concept for the needs of managing the office in a local government, defining the elements of the organization which will be influenced by the five GG principles mentioned before (BACHTLER et al. 2002, p. 3). Among the elements of the organization, he mentioned strategy, processes, culture and the assets of the municipality, indicating that, in the case of the last, before proceeding to the processes of planning, the application of the GG concept will mean considering the assets possessed by the municipality, measuring the effectiveness of the used assets of the municipality, considering the possibility of the municipality's residents to influence the way of using the municipal assets, as well as making 
information on the use of municipal assets and their effectiveness available. As real estate constitutes the basic asset of the municipality, the optics proposed by SZUMOWSKI (2012) will be also used in the research process, at the stage of creating the survey questionnaire.

\section{Materials and Methods}

The research was conducted in the municipalities belonging of the Kraków Metropolitan Area defined in the Area Development Plan of Małopolska Province (PLAN... 2003, p. 55). In the document, we can read that the Kraków Metropolitan Area is a specific functional region, including a big city, namely Kraków Metropolis, with a neighboring complex of settlement units connected with the metropolis by various interactive relations. At present, in addition to Kraków, the area comprises 50 municipalities, including 34 of a rural character, 15 urban-rural municipalities and 1 urban municipality (for more about Kraków Metropolian Area see. GŁUSZAK, MARONA 2015, pp. 143-148), located jointly in nine districts (Bocheński, Krakowski, Miechowski, Myślenicki, Olkuski, Proszowicki, Wadowicki, Wielicki and Kraków).

The survey was conducted in January 2016. The survey questionnaires, consisting of 5 questions (including two open ones), were sent by traditional post to all municipalities belonging to Kraków Metropolitan Area along with a request to fill them out. One of the questions was a matrix question and included questions concerning eighteen issues directly referring to the NPM and GG concepts. A so-called accompanying letter was attached to the package, which included information about the survey objectives and the means of publishing the obtained results. Twenty-five questionnaires were returned, that is $49 \%$ of the sent ones. Among the municipalities which completed the survey questionnaire were 15 rural municipalities, 9 urban-rural municipalities and Kraków (city with district rights). In all the cases, the individuals completing the survey questionnaire were directly involved in real estate management, holding the positions of inspectors, mostly managerial.

\section{Results}

The conducted research did not prove the hypothesis according to which PG is the basic model in Polish municipal real estate management. It should be rather asserted that the concept, in fact its more practical and more detailed version, namely GG, is merely a set of tools from which most of the municipalities choose only some. The detailed results of the research in this context, aiming to assess the scope using Good Governance principles in municipal real estate management in municipalities belonging to the Kraków Metropolitan Area have been presented in tabular form (Table 1).

Table 1

The use of Good Governance principles in municipal real estate management in municipalities belonging to the Kraków Metropolitan Area

\begin{tabular}{clc}
\hline GG principles & \multicolumn{1}{c}{ Research findings } & Evaluation \\
\hline effectiveness & The vast majority of the surveyed municipalities $(92 \%)$ declare the \\
& timeliness of the performed real estate management tasks. Most of \\
& the municipalities also declare the full completion of tasks planned \\
& for a given financial year $(72 \%)$. However, the lack of any \\
& developed ratios enabling the assessment of the effectiveness of real \\
& estate management is observed ( $80 \%$ of the municipalities do not \\
& perform ratio analysis). Moreover, only three municipalities $(12 \%)$ \\
& declared performing a comparative analysis of the results of \\
& management with other municipalities. \\
\hline openness & 52\% of the examined municipalities declared that complete \\
& information concerning the state of municipal real estate can be \\
& found on office websites of the municipalities (44\% of the \\
& municipalities gave a negative answer). The question of publicizing \\
& information about the plans for investments, repairs and \\
& modernization of municipal assets looks similar (56\% of the \\
& municipalities publicize part or all of this type of information by \\
& means of a website). The last question in this category concerned \\
publicizing reports on accomplishments in the context of municipal
\end{tabular}


real estate management; only $24 \%$ of the municipalities publish this type of report online.

participation One of the questions concerned the residents' possibility to express opinions and co-decide in an organized way (e.g. an Internet survey, a meeting with residents) on selected aspects of real estate management (e.g. the way of developing a city park, the color of a municipal school façade, etc.). $60 \%$ of the municipalities declared that, over the last two years, there had been at least one such occasion ( $40 \%$ gave a negative answer).

accountability $86 \%$ of the respondents declared that organizational units dealing with municipal real estate management are assessed internally. In $80 \%$ cases, the level of the fulfillment of tasks being the responsibility of the organizational units dealing with real estate management is discussed at management meetings. In $60 \%$ of the municipalities, organizational units responsible for real estate management prepare accomplishment reports at the end of the year.

coherence Due to difficulties in analyzing the scope of applying the coherence principle in municipal real estate management (by means of a survey questionnaire), this aspect was not evaluated.

Symbol "+" means a large scope of applying an individual GG principle in municipal real estate management, symbol (-) stands for a small scope of application, whereas symbol ",+-" - an average scope.

\section{Source: own study.}

Also the hypothesis concerning the use of NPM in the practice of municipal real estate management in Poland was not proved. As for the NPM standards described by Hood (1990), such as (1) explicit standards and measure of performance, and (2) greater emphasis on output control, just as in the case of GG, they are fulfilled only fragmentarily. For example, it is hard to talk about any effective control of the real estate management process, whose essence is comparing the planned state with the completed state when as many as $52 \%$ of the municipalities do not have plans for municipal asset use. At the same time, it is a signal of non-observance of the provisions of the Real Estate Management Act see Art. 23 and 25), which imposes an obligation to prepare such plans on the executive bodies of municipalities and, at the same time, the confirmation of the results of other research into deficiencies in public real estate management in Poland (ŹRÓBEK, ŹRÓBEK 2008, Gospodarowanie gminnym... 2008, MARONA, GLUSZAK, 2011, WOJEWNIK-FILIPKOWSKA et al. 2015). Moreover, what arises from the research is that the vast majority of municipalities do not differentiate remunerations for the employees participating in the real estate management process. In the majority of municipalities, bonuses for employees connected with municipal real estate management also do not depend either on the effects of their work or on the degree of meeting objectives (only in two cases was the answer "definitely yes"). Apart from this, what results from the research is that municipalities seldom decide to use outsourcing solutions in real estate management (only $28 \%$ of municipalities use such a solution).

The relatively best situation is in the context of the NPM postulate concerning the professionalization of personnel. In $88 \%$ of cases, the persons taking part in municipal real estate management complete cyclic, profiled trainings. In the majority of cases $(64 \%)$, municipality employees participating in real estate management have a professional education (e.g. real estate management, spatial development, geodesy, etc.). It is worth mentioning that the lack of professional education was marked mainly in rural municipality offices, in which the responsibility for the fulfillment of tasks related to real estate management must by combined by employees with other duties. Moreover, what arises from the research is that there is a relatively high number of employees responsible for real estate management in the examined municipalities $(44 \%)$ who have experience in the private sector.

One of the last questions in the survey questionnaire concerned the familiarity of the respondents with the NPM and GG concepts. It turns out that the majority of the respondents declared unfamiliarity with these concepts (respectively $64 \%$ and $60 \%$ of negative answers). 


\section{Conclusion}

During the research, the research hypotheses were rejected. It should be stated that both the NPM and the GG concept do not constitute a benchmark model in the practice of municipal real estate management in Poland. The concepts are treated more as a set of tools from which the majority of municipalities choose only some, selected instruments. In this context, there is a necessity to conduct further research which would focus on the analysis of the conditionings related to choosing specific public management tools by municipalities in the process of real estate management. In this context, it seems necessary to extend the analyses by qualitative analyses, with the use of the case study method.

In the context of the conclusions drawn from the conducted research, it is also necessary to remember the research limitations, for at least three reasons. Firstly, the research was conducted within one metropolitan area: it seems necessary to carry out research on a bigger research sample in the future. Moreover, as in other research of this type (RYMARZAK, TROJANOWSKI 2013, GROSS, ŹRÓBEK 2013), the reliability of the information provided cannot be adequately verified, and thus, there is no certainty whether the information and opinions obtained are unbiased and give a full picture. Therefore, the postulate concerning the fulfillment of qualitative research expressed before takes on special significance.

\section{References}

BACHTLER J., Wishlade F., Yuill D., 2002, The White Paper on European Governance: EPRC Comments, European Policies Research Centre, UNIVERSITY OF STRATHCLYDE.

Communication from the Commission of 25 July 2001, European Governance - A White Paper, COM(2001) 428 final - Official Journal C 287 of 12.10.2001.

CYFERT S., DYDUCh W., LATUSEK-JURCZAK D., NiEMCZYK J., SOPIŃSKA A., 2014, Subdyscypliny w naukach o zarzadzaniu - logika wyodrębniania, identyfikacja modelu koncepcyjnego oraz zawartość tematyczna (Subdisciplines in Management Sciences - the Logic of Selecting and Identifying a Conceptual Model as well as Thematic Content) Organizacja i kierowanie Nr 1, (Organization and Management No. 1).

Gospodarowanie gminnymi zasobami nieruchomości (Managing Municipal Real Estate Stock), 2008, pod red. (ed. by) R. Wiśniewskiego, Wydawnictwo Uniwersytetu Warmińsko - Mazurskiego w Olsztynie (University of Warmia and Mazury in Olsztyn), Olsztyn.

Good Governance in Land Tenure and Administration, 2007, FAO Land tenure studies, Rome.

GŁUSZAK M., MARONA B., 2015, Podatek katastralny. Ekonomiczne uwarunkowania reformy opodatkowania nieruchomości (Property Tax. Economics Issues of Ad Valorem Reform,), Wydawnictwo Poltext (Poltext), Warszawa.

Gross M., ŹRÓBEK R., 2015, Good Governance in Some Public Real Estate Management Systems, Land Use Policy, Vol. 49. DOI:10.1016/j.landusepol.2015.08.017.

Gross M., ŹRÓBEK R., Public Real Estate Management in Post Socialist Countries, Real Estate Management and Valuation, Vol. 21, No. 4, 2013. DOI: 10.2478/remav-2013-0032.

Haque M. S., 2007, Revisiting the New Public Management, Public Administration Review, Vol. 67, No. 1. Hood CH., 1991, A Public Management for All Seasons, Public Administration, Vol. 69.

KASK K. 2014, Public Sector Real Estate Asset Management Models and Their Evaluation, University of Tartu, Estonia.

KICKERT W. J. M., 1997, Public Governance in the Motherlands: an Alternative to Anglo-American 'Managerialism', Public Administration, Vol. 75, Issue 4.

Lu Y., 2001, New Public Management Reforms in Public Asset Management as the State Governments of the United States, International Conference on Public Administration (ICPA th).

MARONA B., GŁUSZAK M., 2011, Niesprawności zwiazane $z$ gospodarowaniem nieruchomościami komunalnymi $w$ Polsce (The main problems of the municipal property management in Poland), [w:] Inwestycje i nieruchomości - wyzwania 21 wieku, (pod red. A. Nalepki) ([in:] Investments and Real Estate - the Challenges of the 21st century, (ed. A. Nalepka)), Fundacja Uniwersytetu Ekonomicznego w Krakowie, (The Cracow University of Economics Foundation), Kraków.

MARONA B., 2014, Zakres wykorzystania narzędzi zarzadzania publicznego przez wybrane urzedy miast w Polsce w kontekście obstugi inwestorów (Public Management Tools in the Context of Investor Service: Case of Polish Municipalities), Zarządzanie i Finanse, Journal of Management and Finance, Nr 4. (Journal of Management and Finance, No. 4).

OECD, 1990, Public Management Developments Survey. Paris. 
OECD, 1993, Public Management Developments Survey. Paris.

OECD, 1995, Governance in Transition. Public Management Reforms in OECD Countries. Paris.

OECD, 2009, Current and Future Public Governance Challenges, in: Government at a Glance 2009, OECD PUbLISHING. http://dx.doi.org/10.1787/9789264061651-4-en.

Perry, J. L., Kraemer K., 1983, Public Management: Public and Private Perspectives, Palo Alto, CA: MAYFIELD.

Plan Zagospodarowania Przestrzennego Województwa Małopolskiego (Małopolskie Province Spatial Development Plan), 2003, Urząd Marszałkowski Województwa Małopolskiego, (Marshal Office of Malopolska Region in Krakow), Krakow.

Pollitt Ch., BoucKaert G., 2004, Public Management Reform. A Comparative Analysis. Second Edition, OXFORD UNIVERSITY PRESS, 2004.

Public Management and Governance, 2009, Second edition, Edited by Tony Bovaird and Elke Löffler, ROUTLEDGE 2009.

RymarzaK M., Trojanowski D., 2013, Asset Mnagement of the Public Sector in Poland, Real Estate Management and Valuation, Vol. 21, No. 1. DOI: 10.2478/remav-2013-0001.

SudoŁ S., 2014, Podstawowe problemy metodologiczne (The Fundamental Methodological Peoblems of Management Acience), Organizacja i kierowanie, Nr 1. (Organization and Management, No. 1).

SzUMOWSKI W., 2012, Koncepcja good governance w doskonaleniu systemu zarządzania urzędu administracji samorzadowej (Good Governance Concept in the Improvement of the Management System of Local Administration Office), Nauki o zarządzaniu, No. 4, Vol. 13. (Management Sciences, No. 4, Vol. 13).

SZUMOWSKI W., 2014, Zarządzanie publiczne - próba systematyzacji koncepcji (Public Management - an Attempt at the Systematization of Concepts), Nauki o zarządzaniu, No. 4, Vol. 21. (Management Sciences, No. 4, Vol. 21).

WojeWNiK - FILIPKOWSKA A., RYMARZAK M., LAUSBERG C., Current Managerial Topics in Real Estate Asset Management, World of Real Estate Journal, Vol. 94, No. 4, 2015. DOI: 10.14659/worej.2015.94.01. 